\title{
The interaction between prothrombin and staphylocoagulase
}

Citation for published version (APA):

Bas, B. M., Muller, A. D., de Graaf, J. S., \& Hemker, H. C. (1975). The interaction between prothrombin and staphylocoagulase. In H. C. Hemker, \& J. J. Veltkamp (Eds.), Prothrombin and related coagulation factors (1 ed., pp. 107-115). Leiden University Press. Boerhaave series for postgraduate medical education Vol. 10

Document status and date:

Published: 01/01/1975

Document Version:

Publisher's PDF, also known as Version of record

\section{Please check the document version of this publication:}

- A submitted manuscript is the version of the article upon submission and before peer-review. There can be important differences between the submitted version and the official published version of record.

People interested in the research are advised to contact the author for the final version of the publication, or visit the DOI to the publisher's website.

- The final author version and the galley proof are versions of the publication after peer review.

- The final published version features the final layout of the paper including the volume, issue and page numbers.

Link to publication

\footnotetext{
General rights rights.

- You may freely distribute the URL identifying the publication in the public portal. please follow below link for the End User Agreement:

www.umlib.nl/taverne-license

Take down policy

If you believe that this document breaches copyright please contact us at:

repository@maastrichtuniversity.nl

providing details and we will investigate your claim.
}

Copyright and moral rights for the publications made accessible in the public portal are retained by the authors and/or other copyright owners and it is a condition of accessing publications that users recognise and abide by the legal requirements associated with these

- Users may download and print one copy of any publication from the public portal for the purpose of private study or research.

- You may not further distribute the material or use it for any profit-making activity or commercial gain

If the publication is distributed under the terms of Article $25 \mathrm{fa}$ of the Dutch Copyright Act, indicated by the "Taverne" license above, 


\section{THE INTERACTION BETWEEN PROTHROMBIN AND STAPHYLOCOAGULASE}

B. M. BAS, A. D. MULLER, J. S. DE GRAAF AND H. C. HEMKER

\section{Introduction}

Thrombin is a two-chain serine protease ( 39,000 daltons), derived from prothrombin (a single-chain protein of about 73,000 daltons) by limited proteolysis (1-5). Staphylocoagulase produces a thrombin-like activity in prothrombin. This activity we call coagulase-thrombin $(6,7)$.

Coagulase-thrombin can be distinguished from normal thrombin in that it is not inhibited by heparin and soybean trypsin inhibitor (8); also its chromatographic behaviour on DEAE-cellulose is different (9).

Soulier found that purified coagulase-thrombin is inhibited by antibodies against prothrombin as well as by antibodies against staphylocoagulase (9). Muller and Hemker showed that the molecular weight of coagulase-thrombin equals the sum of the molecular weights of staphylocoagulase and prothrombin (10). The purpose of this study was to determine whether staphylocoagulase induces activity in prothrombin by limited proteolysis or by a stoichiometric reaction.

\section{EXPERIMENTS}

\section{Generation of activity}

The addition of purified staphylocoagulase to purified prothrombin $(11,13)$ leads to the generation of a product that has both TAMe ${ }^{1}$-esterase activity and the ability to clot fibrinogen.

The amount of esterase activity that evolves is a function of both the quantity of staphylocoagulase and the quantity of prothrombin present. Figure 1 shows that after two minutes the activity in the mixture is maximal and stable. Figure 2 shows that for each concentration of staphylocoagulase

1. $\mathrm{TAMe}=$ tosyl arginine methylester. 


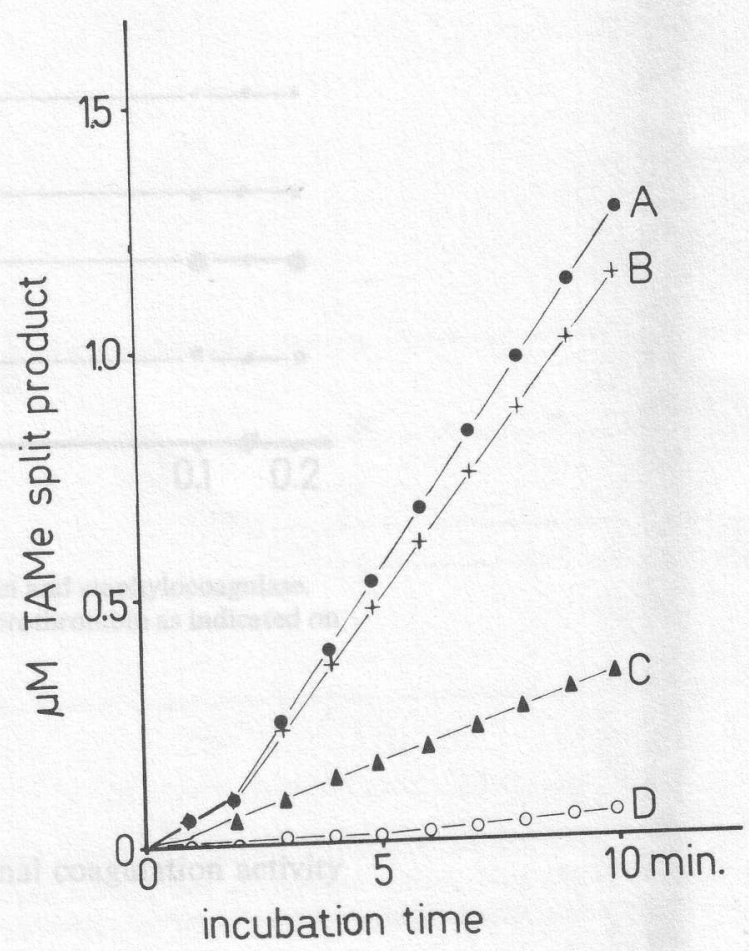

Fig. 1. TAMe hydrolysis by coagulase-thrombin.

The amount of ester hydrolysed is given as a function of time. Reaction mixture C: $0.10 \mathrm{ml}$ staphylocoagulase $(2 \mathrm{mg} / \mathrm{ml})$ and $0.10 \mathrm{ml}$ prothrombin $(10 \mathrm{mg} / \mathrm{ml}) ; 4.8 \mathrm{ml}$ TAMe $5 \mathrm{mM}$ ( $\mathrm{pH} 7.35$ ) in $0.1 \mathrm{M} \mathrm{NaCl}$. In the other mixtures prothrombin or staphylocoagulase solutions were (partially) replaced by $0.1 \mathrm{M} \mathrm{NaCl}$ so as to obtain the concentrations indicated below. No observable esterase activity developed when no prothrombin was added. Final concentrations: A: staphylocoagulase $40 \mu \mathrm{g} / \mathrm{ml}$; prothrombin $50 \mu \mathrm{g} / \mathrm{ml}$

B: staphylocoagulase $40 \mu \mathrm{g} / \mathrm{ml}$; prothrombin $200 \mu \mathrm{g} / \mathrm{ml}$

C: staphylocoagulase $10 \mu \mathrm{g} / \mathrm{ml}$; prothrombin $200 \mu \mathrm{g} / \mathrm{ml}$

D: staphylocoagulase $0 \mu \mathrm{g} / \mathrm{ml}$; prothrombin $200 \mu \mathrm{g} / \mathrm{ml}$.

there is a lowest concentration of prothrombin that gives maximal activity. Any further increase in prothrombin concentration will not raise the esterase activity further. The same phenomenon can be observed with the coagulation times: for each concentration of staphylocoagulase there is a lowest concentration of prothrombin that will cause maximal coagulation activity, i.e. a minimal coagulation time (fig. 3 ).

This type of experiment indicates the minimal concentration of prothrombin that will just cause optimal activity in a given amount of staphylocoagulase (and vice versa). The pairs of concentrations thus found are plotted in 


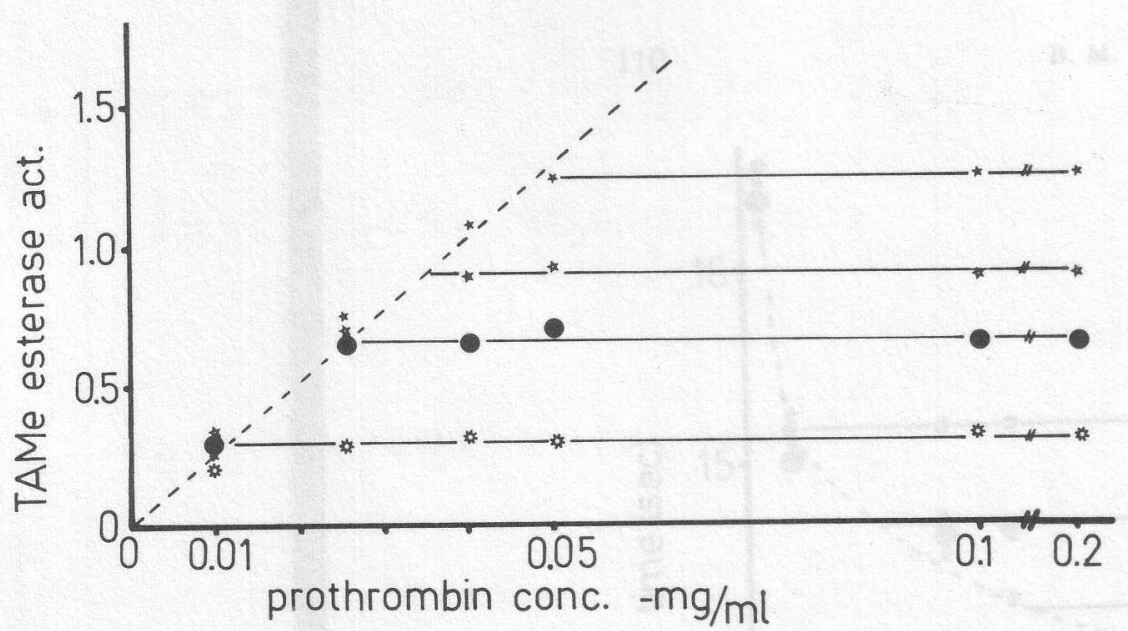

Fig. 2. Esterase activity in $\mu \mathrm{M} / \mathrm{min}$ in mixtures of prothrombin and staphylocoagulase. The esterase activity was determined with varying amounts of prothrombin as indicated on the abcissa and the following amounts of staphylocoagulase:

约 : $10 \mu \mathrm{g} / \mathrm{ml}$

- $: 20 \mu \mathrm{g} / \mathrm{ml}$

诧: $30 \mu \mathrm{g} / \mathrm{ml}$

$\star$ : $40 \mu \mathrm{g} / \mathrm{ml}$.

fig. 4. Optimal esterase activity coincided with optimal coagulation activity (fig. 2 and 3).

\section{Estimation of the molecular weight}

Preparations of prothrombin, staphylocoagulase, coagulase-thrombin and normal thrombin were subjected to gelfiltration on various types of material. Crude preparations of staphylocoagulase digested Sephadex to some extent, and the behaviour of prothrombin on Sephadex was also anomalous. We therefore changed to polyacrylamide gels. Biogel P-150 showed the most appropriate fractionation range. The molecular weight was determined from the partition coefficient de modo Andrews (14). Dextran blue (molecular weight: $>150,000)$ was used to estimate the void volume; alcohol dehydrogenase (molecular weight: 126,000), bovine serum albumin (molecular weight: 70,000), ovalbumin (molecular weight: 43,000), lactate dehydrogenase (molecular weight: 36,000 ), and chymotrypsin (molecular weight: 25,700 ) were used as reference substances. Prothrombin, staphylocoagulase and thrombin were run separately five times each. Coagulase-thrombin was obtained in three ways: i.e. using: 


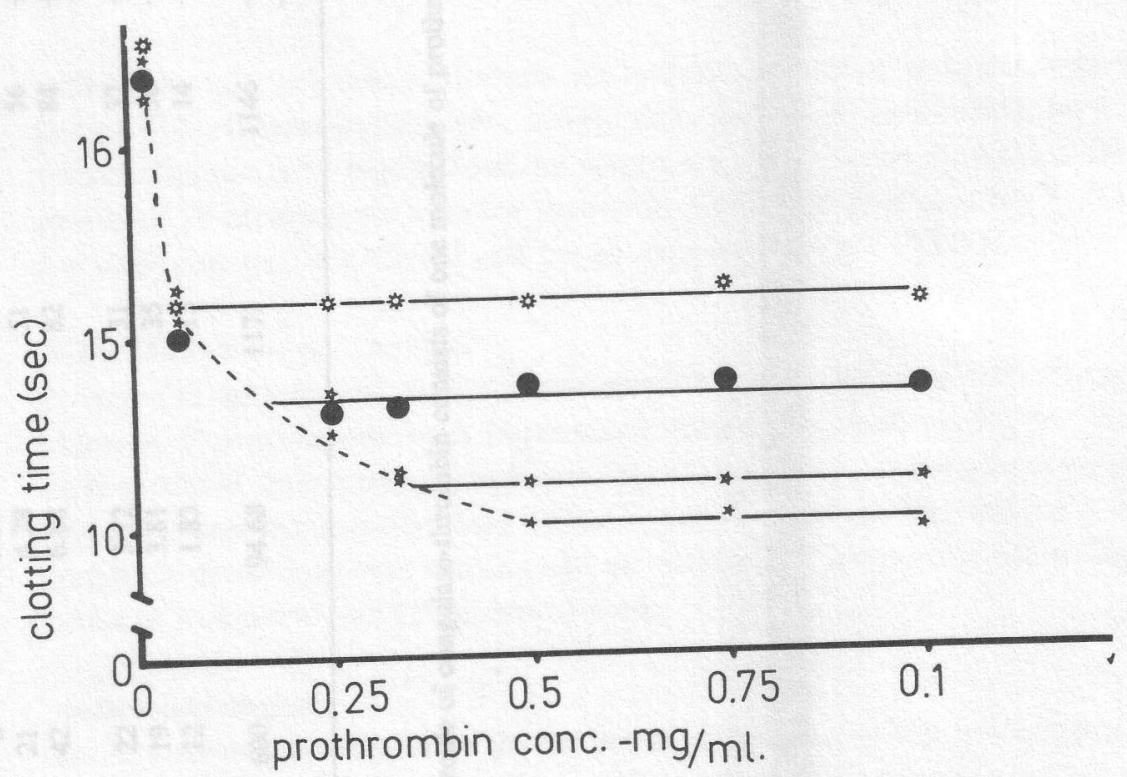

Fig. 3. Clotting activity in mixtures of prothrombin and staphylocoagulase.

The coagulation activity was determined with varying amounts of prothrombin, as indicated on the abcissa, and the following amounts of staphylocoagulase:

勇: $10 \mu \mathrm{g} / \mathrm{ml}$

: $20 \mu \mathrm{g} / \mathrm{ml}$

交: $30 \mu \mathrm{g} / \mathrm{ml}$

$\star$ † : $40 \mu \mathrm{g} / \mathrm{ml}$.

a. roughly equimolar amounts of staphylocoagulase and prothrombin;

b. an excess of prothrombin; or

c. an excess of staphylocoagulase.

In case a) a peak of coagulase-thrombin activity was obtained, followed incidentally by a very small peak of either prothrombin or staphylocoagulase. In case b) the peak of coagulase-thrombin was followed by a peak of prothrombin and in case c) by a peak of staphylocoagulase. The positions of these peaks were used to calculate partition coefficients. Each type of experiment was repeated five times. Essentially the same results were found at $\mathrm{pH}$ values of $6,6.5,7.35,7.5$ and 8 in both the absence and presence of $0.15 \mathrm{M}$ $\mathrm{NaCl}$.

For staphylocoagulase, a molecular weight of 61,000 was found; for thrombin this value was 37,000 , for prothrombin 74,000 , and for coagulasethrombin 135,000 .

Molecular-weight determinations were also carried out by means of 


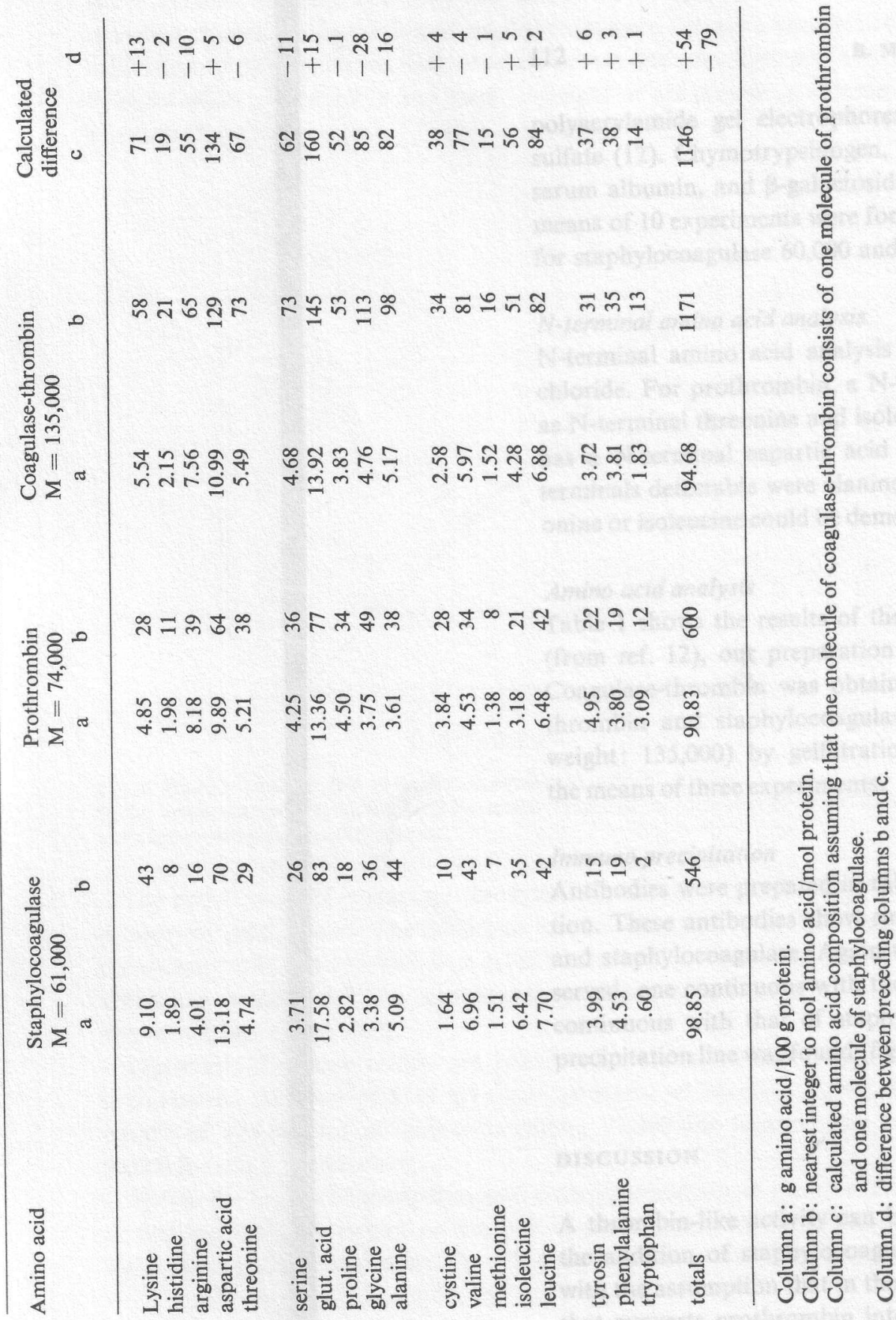


polyacrylamide gel electrophoresis in buffers contaning sodium dodecyl sulfate (12). Chymotrypsinogen, lactate dehydrogenase, ovalbumin, bovine serum albumin, and $\beta$-galactosidase were used as reference molecules. The means of 10 experiments were for thrombin 39,000 , for prothrombin 72,000 , for staphylocoagulase 60,000 and for coagulase-thrombin 125,000 .

\section{$N$-terminal amino acid analysis}

$\mathrm{N}$-terminal amino acid analysis was carried out by labeling with dansylchloride. For prothrombin, a N-terminal alanine was confirmed (5) as well as $\mathrm{N}$-terminal threonine and isoleucine for thrombin (5). Staphylocoagulase has a N-terminal aspartic acid (12). In coagulase-thrombin the only Nterminals detectable were alanine and aspartic acid. No trace of either threonine or isoleucine could be demonstrated.

\section{Amino acid analysis}

Table 1 shows the results of the amino acid analysis of staphylocoagulase (from ref. 12), our preparation of prothrombin, and coagulase-thrombin. Coagulase-thrombin was obtained by mixing equimolar amounts of prothrombin and staphylocoagulase and separating the product (molecular weight: 135,000) by gelfiltration on Biogel P-150. The values represent the means of three experiments.

\section{Immuno precipitation}

Antibodies were prepared in rabbits against a coagulase-thrombin preparation. These antibodies show single precipitation lines against prothrombin and staphylocoagulase. Against coagulase-thrombin a double line was observed, one continuous with the precipitation line of prothrombin, another continuous with that of staphylocoagulase. Against normal thrombin no precipitation line was found (fig. 5).

\section{DISCUSSION}

A thrombin-like activity can be induced in a prothrombin preparation by the addition of staphylocoagulase. The data in figure 1 are incompatible with the assumption that in this system staphylocoagulase acts as an enzyme that converts prothrombin into thrombin. The amounts of both staphylocoagulase and prothrombin determine the final amount of esterase activity, whereas the velocity of generation of this activity is not influenced by chan- 
ges in the concentration of staphylocoagulase. From figure 2 and 3 it can be seen that at each concentration of staphylocoagulase there is a smallest concentration of prothrombin that causes optimal activity. Optimal activity is found when prothrombin and staphylocoagulase are present in equimolar amounts (fig. 4).

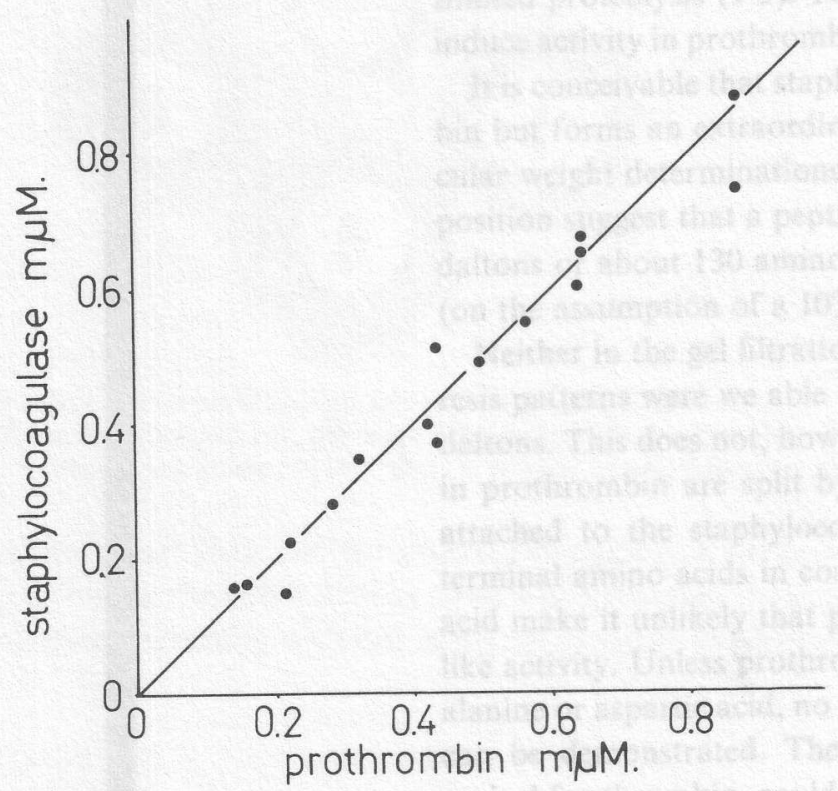

Fig. 4. Ratio of prothrombin to staphylocoagulase at optimal activity.

Molar concentrations calculated for a molecular weight of prothrombin of 73,000 daltons and staphylocoagulase 61,000 daltons.

The active product (coagulase-thrombin) can be separated from the components by gel filtration. The molecular weight calculated from the results of these experiments, is 135,000 . This value can be interpreted as the sum of the molecular weights of the constituent proteins (prothrombin: 74,000; staphylocoagulase: 61,000 ).

Essentially the same results are found when the molecular weights are estimated on the basis of SDS gel electrophoresis, which gives a molecular weight of 125,000 for coagulase-thrombin, 72,000 for prothrombin, and 60,000 for staphylocoagulase.

Within the limits of the experimental error, the amino acid composition of thrombin-coagulase is equal to the sum of the amino acid compositions of staphylocoagulase and prothrombin. It therefore seems that one molecule of 
thrombin-coagulase results from the reaction between one molecule of prothrombin and one molecule of staphylocoagulase.

As for all of the other serine-protease zymogens, the generation of thrombin activity from prothrombin under physiological circumstances is due to limited proteolysis (1-5). Trypsin and a fraction from Echis carinata venom induce activity in prothrombin in a comparable way $(15,16)$.

It is conceivable that staphylocoagulase splits covalent bonds in prothrombin but forms an extraordinarily stable enzymeproduct complex. The molecular weight determinations and the determinations of the amino acid composition suggest that a peptide with a molecular weight of maximally 14,000 daltons or about 130 amino acid residues could split off during this process (on the assumption of a $10 \%$ error in the molecular weight determinations).

Neither in the gel filtration elution pattern nor in the SDS gel electrophoresis patterns were we able to demonstrate polypeptides smaller than 50,000 daltons. This does not, however, preclude the possibility that covalent bonds in prothrombin are split by staphylocoagulase, all the products remaining attached to the staphylocoagulase. Nevertheless, the finding that the $\mathrm{N}$ terminal amino acids in coagulase-thrombin consist of alanine and aspartic acid make it unlikely that proteolysis underlies the generation of thrombinlike activity. Unless prothrombin is split so as to render another $\mathrm{N}$-terminal alanine or aspartic acid, no new N-terminal and hence no form of proteolysis can be demonstrated. The $\mathrm{N}$-terminals threonin and isoleucine, that are typical for thrombin, could not be found in coagulase-thrombin.

Figure 5 shows that antibodies directed against coagulase-thrombin precipitate with prothrombin and staphylocoagulase, but not with thrombin. The fact that with coagulase-thrombin two precipitation lines are obtained, one continuous with prothrombin, the other with staphylocoagulase, can be explained by assuming that coagulase-thrombin dissociates under the experimental conditions. This is slightly puzzling as under a variety of other experimental procedures (gel filtration, column chromatography, SDS polyacrylamide gel electrophoresis) we did not obtain separation. Alternatively, one can imagine that immunisation against coagulase-thrombin gives rise to two populations of antibodies recognising the antigenic determinants of the prothrombin and the coagulase part separately. The problem is under further investigation. Anyhow, the pattern is compatible with the concept of thrombin-coagulase consisting as a complex of prothrombin and staphylocoagulase but not having antigenic determinants in common with thrombin. 


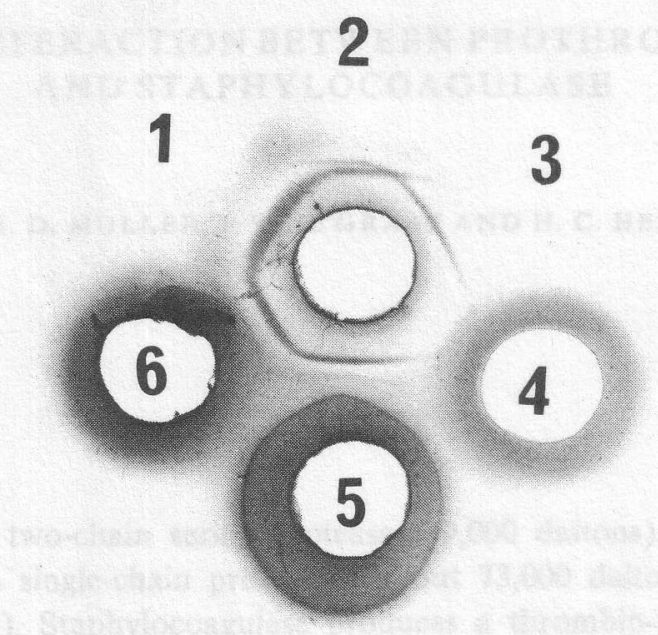

Fig. 5. Double immunodiffusion of an antibody against coagulase-thrombin.

The centre well contains the antibody, the other wells contain: 1 . prothrombin; 2 . coagulase-thrombin; 3. staphylocoagulase; 4. thrombin; 5. normal serum; 6. normal plasma.

We conclude that apart from limited proteolysis there is a fundamentally different way to obtain thrombin activity from a prothrombin molecule, viz. by a stoichiometric interaction with one molecule of staphylocoagulase.

\section{REFERENCES}

1. Mann, K. G., C. M. Heldebrant and D. N. Fass, J. biol. Chem. 246, 6106-6114 (1971).

2. Heldebrant, C. M. and K. G. Mann, J. biol. Chem. 248, 3642-3652 (1973).

3. Owen, W. G., C. T. Esmon and C. M. Jackson, J. biol. Chem. 249, 594-605 (1974).

4. Jesty, J. and M. P. Esnouf, Biochem. J. 131, 791-799 (1973).

5. Magnusson, S., In The enzymes (P. D. Boyer, ed.) 3rd. ed. Vol. 3 277-321, Acad. Press.

6. Tager, M., Yale J. Biol. Med. 20, 487-501 (1948).

7. Tager, M., J. exp. Med. 104, 675-686 (1956).

8. Drummond, M. C. and M. Tager, J. Bact. 83, 975-980 (1962).

9. Soulier, J. P., O. Prou-Wartelle and L. Hallé, Thrombos. Diathes. haemorrh. 17, 321-331 (1967).

10. Muller, A. D. and H. C. Hemker, Abstracts 6th FEBS Meeting, Madrid. no. 834 (1968).

11. Devilee, P. P., J. S. de Graaf and J. M. v. d. Voort-Beelen and B. M. Bas, This issue. p. 93-98.

12. Bas, B. M., A. D. Muller and H. C. Hemker, Biochem. biophys. Acta 379, 164-171 (1975).

13. Devilee, P. P., H. C. Hemker and B. M. Bas, Biochem. biophys. Acta 379, 172-179 (1975).

14. Andrews, T., Biochem. J. 91, 222-233 (1964).

15. Engel, A. M. and B. Alexander, Biochem. biophys. Acta 320, 687-700 (1973).

16. Schieck, A., F. Kornalik and E. Habermann, Naunyn-Schmiedebergs Arch. Pharm. 264, 259 (1969). 